\title{
The Transformation of Language Functions: Sociological Reflection
}

\section{B. R. Mogilevich}

Bronislava R. Mogilevich, https://orcid.org/0000-0002-4986-9183, Saratov State University, 83 Astrakhanskaya St., Saratov 410012, Russia, mogilevich@sgu.ru

The article considers the language functions evolution in correlation with society development. Language functions are presented from the point of view of various theoretical methodological approaches: behavioral, structural-functional, discourse practices, symbolic interactional, and social constructional. The special role of construction language function, as the most significant under information society, is pointed out. Some examples of this language function activity in establishing national states are given. It is stated that any language makes it possible for its speakers to generate and percept sociocultural information. In conclusion, languages' special mission of preserving their speakers' socio-cultural heritage is focused on.

Keywords: language functions, social construct, information society, socio-cultural heritage, discourse.

\section{Трансформация функций языка: социологическая рефлексия}

\section{Б. Р. Могилевич}

Могилевич Бронислава Рафаиловна, доктор социологических наук, профессор кафедры английского языка для гуманитарных направлений и специальностей, Саратовский национальный исследовательский государственный университет имени Н. Г. Чернышевского, mogilevich@sgu.ru

В статье рассмотрена эволюция языковых функций в корреляции с развитием социума. Языковые функции представлены в контексте разных теоретико-методологических подходов: бихевиоризма, структурного функционализма, дискурсивных практик, символического интеракционизма, социального конструктивизма. Выделена особая роль конструктивной функции языка как наиболее значимой в эпоху информационного общества. Приведены примеры действия конструктивной функции языка при создании национальных государств. Подчеркнуто, что любой язык дает возможность его носителям генерировать и воспринимать социокультурную информацию. В заключение акцентирована особая роль языков для сохранения социокультурного опыта их носителей.

Ключевые слова: языковые функции, социальный конструкт, информационное общество, социокультурное наследие, дискурс.

DOI: https://doi.org/10.18500/1818-9601-2019-19-4-389-391

Human society cannot exist without a language, which is universal by its nature. Languages preserve their speakers' unity in spite of social barriers, therefore they make human society alive in time and space. Language investigations are impossible without considering social conditions of their speakers'

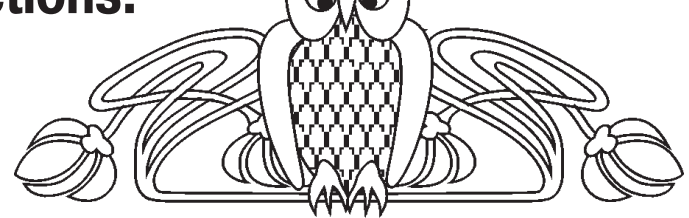

lives. From synchronic point of view, any language presents itself as a unified system, all its elements constructing a unique structure. According to T. Parsons, any language is a universal symbolic system, and only a human being is capable of learning and using this phenomenon conditioned by humans' specific genetic characteristics. Consequently, any humans' verbal and non-verbal means of communication are made by means of a language [1].

According to C. Levi Strauss, human communication implies 3 levels: messages exchange, conveniences exchange and marriage couples exchange. And all these types of exchange are determined by language usage. C. Levi Strauss put forward 3 reasons for this statement:

- these levels' ontogenesis and philogenesis imply language usage;

- these levels are presented in the form of semiotic behavior, speech-wise and particular;

- all types of non speech behavior can be easily transformed into speech-wise ones [2, p. 99].

E. Durkheim, notifying the main role of linguistics among humanities, put forward an idea of linguistic sociology [3, p. 18-22] R. Murton in his functions' theory revealed 5 meanings of the concept "function" in the form of the following oppositions: open-latent; positive-negative, which to a great extent can be attributed to any language [4, p. 19].

However, the new stage of society development conditioned by establishing information society put forward language problems to the forefront of social life. As a language is a social product and a complex system its rules can be described as the activity of its various functions. The functions, in their turn, demonstrate the way the system elements work in relation to each other and the system itself. In general, any system functions make it possible to construct the unified picture of any phenomenon. The function combination, therefore, provides for making the taxonomic representation of the system. As for a language, the 3 function language model based on information types had been known up to the middle of the $20^{\text {th }}$ century K. Pike proposed a unified languages' model in their social contexts. He considered any language as its speakers' behavior display. The cognitive function was considered to be the main one and was aimed at expressing ideas, concepts and thoughts. This function, according to behavior methodology, expressed language understanding as a tool of expressing thoughts. The second function, an evaluating one, provided the relationships of communication partners. The third 
function, an effective one, expressed the processes of emotion and feelings exchange [5, p. 60].

R. Yakobson proposed his own model of language functions. It was focused on the correlation between speech aspects and language functions. The transition from one aspect to another determines language functions activity. The following 5 language functions were distinguished within the frame of this theory:

- emotive - an addressee's aim is to treat communication situation;

- cognitive - the main attention is paid to an addressant, mainly to using vocatives (appeals), and imperatives (indications), both aimed at attracting attention and motivating to activity;

- contextual - the main focus is laid on the theme, content, and discourse;

- report - represents messages themselves;

- contact - using a language for starting, maintaining, and terminating communication;

- code - describing any even/fact by language means [6, p. 110].

According to M. Hallyday's theory of sociological semantics, 7 functions of children's language in the course of time transform into adults 3 macro language functions:

- cognitive function includes evaluative and effective aspects of humans' language activity;

- interpersonal function expresses speech habits, speech situations, and personal relations;

- contextual function implies personal choice of speech content characteristics (lexical, grammatical, phonetic, and stylistic) adequate to extralinguistic situation.

The essence of M. Hallyday's theory was the relationship between content, social, and linguistic components of speech generation, therefore, these language macrofunctions were the tools of transforming meaning into speech actions [7, p. 140-165].

N. V. Mechkovskaya's taxonomy of language function, as the fullest one, is presented by the following components:

- communicative function is the main one and implies the presence of an addressee, an addressant, communication itself, and information; cognitive function means language usage in mental activity - perception, judgements, conclusion, comparison, analysis, memorizing, and preserving information;

- regulative function reveals itself in expressing addressee's intentions and goals in relation to an addressant in term of illocution and perlocution;

- emotional-expressive function actualizes itself in speaker's personal/subjective attitude to utterance content, mainly by means of intonation;

- fatic (establishing contact) function is actualized mainly in greetings, congratulations, common topics (weather, prices, city transport, TV shows, etc) and is dominated by peoples' social status, education level, territorial and gender characteristics;

- metalanguage function implies explaining words' meanings (explaining terms, abbreviations, reductions, and so on;
- esthetic function reflects language users attitude to a language itself, namely to the texts, generated by people, in terms of the texts' beauty, emotional content, stylistic variety, and is manifested, mainly, in fiction, poetry in particular;

- magic function is contained in taboo, swears, incantations, and religious texts, and is actualized in conventional character of language usage (names, word order), aimed at manipulating over others by means of language devices [8].

The second half of twentieth century is characterized by establishing the phenomenon of information society in which generating, receiving, percepting, and interpreting information became the most important factors human's lives [9]. It was accompanied by the phenomenon of "linguistic turn" in all humanities' investigations which meant that personal characteristics became the main tool of constructing social reality. The term "discourse" came to be used to describe various social processes in the context of social actors' speech characteristics, including extralinguistic situations of peoples' social activity. Moreover, one more language function came into being - a constructive one. This function provided language users to make cognitive actions in frames of their everyday lives' and interpersonal communication. Establishing social relations, mastering social roles in the course of socialization, defines interaction and dialectics between an individual and a language. It means symmetric and asymmetric development of language functions and language structures, for example, post-industrial societies use developed language systems (grammatical, lexical, stylistic), they are presented by English, Russian, French, German, etc. On the contrary, the languages of national minorities lack various grammatical categories (terminology, tense system, numbers, and so on). Moreover, languages play a leading role in establishing national states, for example, English was the main constructive tool in establishing the United Kingdom, the USA - unifying numerous immigrants from various parts of the world. Or, Hebrew, the language of the Bible, contributed to a great extent to establishing modern Israel [10].

Thus, language evolution is inseparable from human society development. It is a social construction, functioning in the form of a system and various substystems. In the course of mastering languages, native and foreign ones, humans take part in intersubjective interaction. In their turn, all languages absorb their speakers' life experience and construct their own ones in term of culture, politics, and economics and pass over their socio-cultural heritage from one generation to another.

\section{References}

1 Parsons T. The Concept of Society: The Components and Their Interrelations // Parsons T. Societies: Evolutionary and Comparative Perspectives. Engelwood Cliff (NJ), Prentice Hall, 1966. 270 p. 
2 Levi-Strauss C. Social Structure. London, Hachette UK, 2008. $352 \mathrm{p}$.

3 Alpert H. Emil Durkheim and Sociology. New York, Russell \& Russell, 1966. 233 p.

4 Merton R. Yavnye i latentnye funktsii [Explicit and Latent Functions]. Moscow, Direkt-Media, 2007. 50 p. (in Russian).

5 Pike K. L. Language in Relation to a Unified Theory of Human Behavior. The Hague, Mouton, 1971. 762 p

6 Yakobson R. O. Lingvistika i eio otnoshenie $k$ drugim naukam. Izbrannye raboty [Linguistics and Its Relation to Other Sciences. Selected Works]. Moscow, Progress Publ., 1985. 460 p. (in Russian).
7 Halliday M. A. Language Structure and Language Function. New Horizons in Linguistics, 2008, no. 1, pp. 140-165.

8 Mechkovskaya N. B. Sotsial'naya lingvistika [Social Linguistics]. Moscow, Aspekt Press Publ., 2000. 208 p. (in Russian).

9 Castells M. Informatsionnaya epokha: ekonomika, obschestvo, kul'tura [Information Era: Economics, Society, Culture.]. Moscow, GU VSE Publ., 2000. 219 p. (in Russian).

10 Mogilevich B. R. Language Construction of Global Social Reality. Izv. Saratov Univ. (N. S.), Ser. Sociology. Politology, 2016, vol. 16, iss. 3, pp. 286-289 (in Russian). DOI: https://doi.org/10.18500/1818-9601-2016-16-3-286-289

Образец для цитирования:

Mogilevich B. R. The Transformation of Language Functions: Sociological Reflection [Могилевич Б. Р. Трансформация функций языка: социологическая рефлексия] // Изв. Сарат. ун-та. Нов. сер. Сер. Социология. Политология. 2019. Т. 19, вып. 4. C. 389-391. DOI: https://doi.org/10.18500/1818-9601-2019-19-4-389-391

Cite this article as:

Mogilevich B. R. The Transformation of Language Functions: Sociological Reflection. Izv. Saratov Univ. (N. S.), Ser. Sociology. Politology, 2019, vol. 19, iss. 4, pp. 389-391 (in Russian). DOI: https://doi.org/10.18500/1818-9601-2019-19-4-389-391 